GRASAS Y ACEITES 70 (2)

April-June 2019, e297

ISSN-L: 0017-3495

https://doi.org/10.3989/gya.0697181

\title{
To what extent are hake fat and its oil quality affected by the parasite Lernaeocera lusci?
}

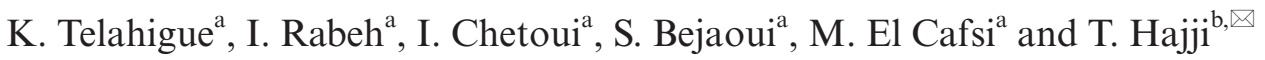 \\ ${ }^{a}$ Univ. Tunis El Manar, Faculty of Sciences of Tunis, Lab. of Ecology, Biology and Physiology of \\ Aquatic Organisms (LR18ES41), 2092 Tunis, Tunisia.
${ }^{b}$ Univ. Manouba, Higher Institute of Biotechnology - Sidi Thabet, Laboratory of Biotechnology and \\ Valorization of Bio-Geo-Resources LR11ES31, 2020 Ariana, Tunisia. \\ Corresponding author: tarekhaj@gmail.com
}

Submitted: 23 June 2018; Accepted: 28 September 2018; Published online: 12 February 2019

\begin{abstract}
SUMMARY: The copepod Lernaeosera lusci is a common ectoparasite of the hake Merluccius merluccius, which constitutes its definitive host. The present study is the first to investigate the impact of $L$. lusci and its infection intensity on the fatty acid (FA) composition and oil quality of its host. The results revealed a substantial decrease in the total FA content, which dropped by 50,70 and $83 \%$ when fish was infected by one (L1), two (L2) and three (L3) parasites, respectively. The lipid profile showed a tendency for a significant decrease in the saturated fatty acid (SFA), monounsaturated fatty acid (MUFA) and polyunsaturated fatty acid (PUFA) levels in all parasitized groups and in a parasite load dependant manner $(\mathrm{p}<0.05)$. The same tendency was observed for the most commonly analysed FA and in particular for essential FA, such as e arachidonic (ARA), eicosapentaenoic (EPA) and docosahexaenoic (DHA) acids, which showed smaller amounts associated with $L$. lusci co-infection. From a nutritional standpoint, our findings revealed that $L$. lusci is able to cause severe deterioration in the nutritional quality of its host oil. In addition to the increase in the thrombogenicity index (IT) and the high atherogenicity index (IA) values, the low hypocholesterolemic / hypercholesterolemic fatty acid ratio $(\mathrm{H} / \mathrm{H})$ and the modest amount of DHA+EPA (20 and $10 \mathrm{mg} / 100 \mathrm{~g}$ ) recorded at heavy infection levels make the parasitized fish inadequate sources of these PUFA and unsuitable for consumers with special dietary needs.
\end{abstract}

KEYWORDS: Fatty acid; Lernaeocera lusci; Merluccius merluccius; Nutritional quality index; Parasite load

RESUMEN: ¿En qué medida la grasa de la merluza y la calidad de su aceite están influenciados por el parásito Lernaeocera lusci? El copépodo Lernaeosera lusci es un ectoparásito común de la merluza Merluccius merluccius que constituye su huésped definitivo. El presente estudio es el primero en investigar el impacto de L. lusci, considerando la intensidad de la infección, la composición de ácidos grasos (FA) y la calidad del aceite de su huésped. Los resultados mostraron una disminución sustancial en el contenido total de FA que se redujo en 50,70 y $83 \%$ cuando el pez se infecta con uno (L1), dos (L2) y tres (L3) parásitos, respectivamente. El perfil lipídico mostró una tendencia a una disminución significativa en los niveles de ácidos grasos saturados (SFA), ácidos grasos monoinsaturados (MUFA) y ácidos grasos poliinsaturados (PUFA) en todos los grupos parasitados y de una manera dependiente de la carga parasitaria $(\mathrm{p}<0.05)$. Se observó la misma tendencia para la mayoría de los FA y, en particular, para los FA esenciales como los ácidos araquidónico (ARA), eicosapentaenoico (EPA) y docosahexaenoico (DHA), que mostraron cantidades reducidas asociadas con la coinfección por L. lusci. Desde un punto de vista nutricional, nuestro descubrimiento reveló que $L$. lusci es capaz de causar un deterioro severo de la calidad nutricional de su aceite huésped. Además del aumento del índice de trombogenicidad (IT) y valores de índice de aterogenicidad (IA) alto, una relación hipocolesterolemia/hipercolesterolemia $(\mathrm{H} / \mathrm{H})$ baja y una cantidad modesta de DHA + EPA $(20$ y $10 \mathrm{mg}) / 100 \mathrm{~g})$ registrados en infecciones graves hacen que los peces parasitados sean fuentes inadecuadas de PUFA y no sean adecuados para consumidores con necesidades dietéticas especiales.

PALABRAS CLAVE: Ácido graso; Carga de parásitos; Índice de calidad nutricional; Lernaeocera lusci; Merluccius merluccius

ORCID ID: Telahigue K https://orcid.org/0000-0001-8841-9911, Rabeh I https://orcid.org/0000-0002-0307-473X Chetoui I https://orcid.org/0000-0002-2259-5397, Bejaoui S https://orcid.org/0000-0002-7953-1722, El Cafsi M https:// orcid.org/0000-0002-9771-1110, Hajji T https://orcid.org/0000-0002-3869-8876

Citation/Cómo citar este artículo: Telahigue K, Rabeh I, Chetoui I, Bejaoui S, El Cafsi M, Hajji T. 2019. To what extent are hake fat and its oil quality affected by the parasite Lernaeocera lusci? Grasas Aceites 70 (2), e297. https://doi. org/10.3989/gya.0697181

Copyright: (C2019 CSIC. This is an open-access article distributed under the terms of the Creative Commons Attribution 4.0 International (CC BY 4.0) License. 


\section{INTRODUCTION}

Interest in the role of fats, fatty acids and in particular omega 3 in human nutrition began several decades ago (Connor, 2000). Thenceforth, a remarkable and growing body of scientific research regarding the health benefits of these compounds has been continuously conducted. Extensive evidence concerning the implication of these fatty acids in health and disease prevention has been published (Ruxton et al., 2004). The existing literature confirms that omega- 3 exerts actions on cardiovascular and inflammatory disease, brain function and mental health (Swanson et al., 2012).

The most readily available source of omega 3 is fish oil, which is particularly rich in eicosapentaenoic acid (EPA; C20:5 $\omega-3$ ) and docosahexaenoic acid (DHA; C20:6 $\omega$-3). In the Mediterranean Sea, the European hake Merluccius merluccius constitutes one of the most popular edible and the most economically important fish species. It is highly prized owing to its high nutritional quality and its excellent organoleptic properties. According to Corrales and Rivero (2013), besides being an excellent source of protein, and minerals, hake can be used as a reference fish commonly consumed and included in heart-healthy diets due to its adequate amounts of omega-3 fatty acids.

It is well known that the fatty acid composition of fish is not constant and can be influenced by intrinsic and extrinsic factors (Satio et al., 1999). Biotic stressors such as parasites can impact the lipid content and fatty acid composition of fish (Hajji et al., 2015). In fact, parasites are known to be ecologically important stressor infections that may alter host physiology and consequently have a negative impact on its health condition. Nonetheless, parasitism is often overlooked in a fish nutritional quality assessment.

The parasitic copepod Lernaeocera lusci, found deep in the branchial arches of M. merluccius, is among the common parasites of a number of flatfish and gadoid species (Van Damme et al., 1994). In comparison to its congeneric species, $L$. branchialis, which is a serious metazoan pathogen that can cause severe pathologies to its host, little is known about the pathogenicity of $L$. lusci. The available data have demonstrated that $L$. lusci is less pathogenic towards its definitive host (Van Damme et al., 1994). Other authors failed to find evidence for the pathogenicity of L. lusci (Evans et al., 1983; Eiras, 1986).

In general, pathogenicity depends on a number of factors including parasite burden. Often, light infection may induce minor damage; whereas heavy loads provoke sever physiological impairment and even death of the host (Woo and Buchmann, 2012). In this context, and among the rare data dealing with the pathogenicity of L. lusci, Van Damme et al.,
(1994) have shown that haematocrit content in hake decreased in relation to the number of $L$. lusci.

With the lack of recent research and the scarcity of the available data on the harmful effects of L. lusci, the pathogenicity of this parasite towards its host M. merluccius still mitigated. The current study attempts to verify for the first time whether the pathogen $L$. lusci can impact its host lipids, and if so, how this varies with different parasite intensities. The results are also discussed from a nutritional point of view in order to provide useful information to the consumer regarding an adequate intake of omega-3 fatty acids.

\section{MATERIALS AND METHODS}

\subsection{Fish samples}

A total of 146 samples of European hake M. merluccius with similar size $(18 \pm 1.5 \mathrm{~cm})$ were bought from fisherman at the port of Bizerte (Tunisian northern waters). The fish were immediately transported to the laboratory in polystyrene, ice-cooled boxes. Only immature specimens were included in this study in order to avoid any inference with the reproduction cycle. All specimens were immediately examined to look for the presence of $L$. lusci. Specimens infected with $L$. lusci were further dissected and only samples without other macro parasites (such as worms) were kept to avoid any bias. The fish were determined to be free from infection with $L$. lusci or other macro parasites were taken as control samples. All the fish were filleted. The fillet samples from the parasitized and unparasitized fish were weighed $(5.0 \pm 0.5 \mathrm{~g})$, and then stored at $-30{ }^{\circ} \mathrm{C}$ until analysis.

\subsection{Total lipid extraction and fatty acid analysis}

Total lipids were extracted from the fillet samples according to the method of Folch et al., (1957), using a mixture of the chloroform-methanol (2:1) solvent containing $0.01 \%$ butylated hydroxytoluene (BHT) as antioxidant. After extraction, the solvent was evaporated under a nitrogen stream and the lipids were dried by vacuum desiccation. Aliquots of total lipids were subjected to transesterification as proposed by Cecchi et al., (1985). The obtained fatty acid methyl esters (FAMEs) were analyzed in an HP 6890 GC (Agilent Technologies, Sacramento, CA, USA) equipped with an Innowax 250 capillary column $(0.25$ inside diameter $\times 30 \mathrm{~m}$ length, $0.25 \mu \mathrm{m}$ film; Agilent Technologies). The carrier gas was nitrogen and the injector temperature was set at $250{ }^{\circ} \mathrm{C}$. The oven was programmed to rise from $50^{\circ} \mathrm{C}$ to $180^{\circ} \mathrm{C}$ at a rate of $4^{\circ} \mathrm{C} \cdot \mathrm{min}^{-1}$, then to reach $220^{\circ} \mathrm{C}$ with a ramp rate of $1.33{ }^{\circ} \mathrm{C} \cdot \mathrm{min}^{-1}$, and finally to stabilize at $220^{\circ} \mathrm{C}$ for $7 \mathrm{~min}$. Chromatographic data were recorded using a Hewlett-Packard ChemStation 
software and FAMEs were identified by comparison of their retention times with those of known standards (Supelco 47085U PUFA No: 3 and Supelco 37 component FAME mix 47885-U). Methyl nonadecanoate (C19:0, sigma) was used as an internal standard and fatty acids were reported as $\mathrm{mg} \cdot \mathrm{g}^{-1}$ wet weight.

\subsection{Oil quality indices}

Data from the fatty acid composition analyses were used to assess the nutritional profile of the lipid fraction. Three indices were used: (i) index of atherogenicity (IA), (ii) index of thrombogenicity (IT) and (iii) hypocholesterolemic/ hypercholesterolenic fatty acid ratio $(\mathrm{HH})$.

The IA and IT indices, which are important tools to estimate the probability of developing coronary heart disease, were calculated according to the Ulbricht and Southgate (1991) equations:

$$
\begin{aligned}
& \text { IA }=([12: 0+(4 \times 14: 0)+16: 0]) /\left(\left[\sum \text { MUFA }+\right.\right. \\
& \left.\left.\sum \text { PUFA }(\omega-6)+(\omega-3)\right]\right) \\
& \text { IT }=(14: 0+16: 0+18: 0) /\left(\left(0.5 \times \sum \text { MUFA }\right)+\right. \\
& \left(0.5 \times \sum \mathrm{n}-6 \text { PUFA }\right)+\left(3 \times \sum \omega-3 \text { PUFA }\right)+ \\
& (\omega-3) /(\omega-6)
\end{aligned}
$$

Where $\Sigma$ MUFA is the sum of monounsaturated fatty acids and $\Sigma$ PUFA is the sum of polyunsaturated fatty acids.

The hypocholesterolemic/hypercholesterolemic index (related to cholesterol metabolism) was determined according to Santos-Silva et al., (2002) equation as follows:

$$
\begin{aligned}
& \mathrm{H} / \mathrm{H}=(18: 1 \omega-9+18: 2 \omega-6+20: 4 \omega-6+ \\
& 18: 3 \omega-3+20: 5 \omega-3+22: 5 \omega-3+ \\
& 22: 6 \omega-3) /(14: 0+16: 0)
\end{aligned}
$$

Further ratios related to fatty acid content were also calculated as PUFA/SFA (polyunsaturated FA/ saturated FA) and $\omega-3 / \omega-6$.

\subsection{Statistical analysis}

Means of three replicates (separately prepared) were calculated by Microsoft Excel software (2016 version). Statistical analyses were carried out using R software version 3.3.3 (R Core Team, 2017). Data were analyzed for normality and variance homogeneity through Kolmogorov-Smirnov and Levene's tests, respectively. One-way analysis of variance (ANOVA) and Tukey HSD's test (at $\mathrm{p}<0.05$ ) were performed so as to detect significant statistical differences. Raw data were arcsine-transformed before analysis when necessary to meet requirements for normal distribution and homogeneity of variances.

\section{RESULTS AND DISCUSSION}

\subsection{Fatty acid profiling}

Table 1 shows the fatty acid profiles in the fillet of the European hake M. merluccius unparasitized and parasitized by the copepod $L$. lusci with different intensities. In the unparasitezed group, the total fatty acid content ( $\mathrm{FA})$, expressed on a wet weight basis, comprised about $0.5 \%$ of the hake fillet $(0.519$ $\mathrm{mg}$ per g) and followed a relative pattern with PUFA $>$ SFA > MUFA. Our findings are in agreement with those of Huynh and Kitts (2009) who reported that unlike other lean fish, the pacific hake exhibited a typical pattern with the highest amount of SFA than MUFA. It was found that Palmitic acid (C16:0) was the predominant fatty acid among the SFA fraction; whereas the most abundant MUFA was oleic acid (C18:1), followed by palmitoleic acid (C16:1) with 0.453 and $0.217 \mathrm{mg} \cdot \mathrm{g}^{-1}$ respectively. The PUFA content reached $2.670 \mathrm{mg} \cdot \mathrm{g}^{-1}$ (constituted about half of the total fatty acids) with higher prevalence of PUFA in the $\mathrm{n}-3$ family (about $70 \%$ of total PUFA) and with a predominance of docosahexanoic acid (DHA, C22:6 $\omega$-3) and to lesser extent, eicosapentaenoic acid (EPA, C20:5 $\omega-3$ ). Our data are comparable to those previously reported for other lean and low-fat fish in which the amounts of DHA generally exceeded those of EPA (Mendez and Gonzalez, 1997; Huynh and Kitts, 2009). In this context, Huynh and Kitts (2009) have reported that the highest DHA amount seems to be an inherent characteristic of lean fish, probably due to their greater ability to retain this fatty acid.

Variations in contents and composition of fatty acids of fish due to parasite infections have been confirmed (Khan, 1988; Hajji et al., 2015). Herein, the decrease in the total FA content of M. merluccius fillet was quantitatively substantial and depended on the L. lusci load. In fact, the FA content dropped by 50,70 and $83 \%$ when the fish was infected by one single (L1), two (L2) and three (L3) parasites, respectively, in comparison to the control. Our results are in line with the findings of Khan (1988), who reported that infection by the copepod L. branchialis resulted in a significant reduction (up to the half) in the fat content of cod.

Within the fatty acid composition, we noticed that there was a tendency for a significant decrease in the SFA, MUFA and PUFA concentrations in all parasitized groups and in a parasite load dependant manner $(\mathrm{p}<0.05)$. Thereby, the L3 group was the most affected one, the SFA, MUFA and PUFA contents decrease by 77.84 and $85 \%$, respectively, compared to the control group. The same observations were made for the majority of fatty acids when analyzed individually. The pronounced effects of $L$. lusci were observed in fish infected with two or more parasites. In fact, the intraspecific competition 
TABLE 1. Fatty acids composition of the muscle of the European hake Merluccius merluccius free from Lernaeocera lusci infection and with different parasite loads (L1: one single parasite, L2: two parasites and L3: three parasites per host). The fatty acid amounts are expressed as $\mathrm{mg} \cdot \mathrm{g}-1$ wet weight in fish muscle.

\begin{tabular}{|c|c|c|c|c|}
\hline Fatty acids & Control L0 $($ Load $=0)$ & Parasitized L1 (load=1) & Parasitized L2 $($ Load = 2) & Parasitized L3 $($ Load $=3)$ \\
\hline C14:0 & $0.188 \pm 0.019^{\mathrm{a}}$ & $0.123 \pm 0.025^{\mathrm{b}}$ & $0.075 \pm 0.009^{\mathrm{c}}$ & $0.025 \pm 0.003^{\mathrm{d}}$ \\
\hline $\mathrm{C} 15: 0$ & $0.081 \pm 0.007^{\mathrm{a}}$ & $0.084 \pm 0.023^{\mathrm{a}}$ & $0.023 \pm 0.003^{\mathrm{b}}$ & $0.006 \pm 0.001^{\mathrm{c}}$ \\
\hline $\mathrm{C} 16: 0$ & $1.223 \pm 0.076^{\mathrm{a}}$ & $0.776 \pm 0.083^{\mathrm{b}}$ & $0.495 \pm 0.033^{\mathrm{c}}$ & $0.269 \pm 0.026^{\mathrm{d}}$ \\
\hline $\mathrm{C} 17: 0$ & $0.101 \pm 0.022^{\mathrm{a}}$ & $0.048 \pm 0.007^{b}$ & $0.028 \pm 0.004^{\mathrm{c}}$ & $0.059 \pm 0.014^{\mathrm{b}}$ \\
\hline C18:0 & $0.303 \pm 0.029^{\mathrm{a}}$ & $0.290 \pm 0.022^{\mathrm{a}}$ & $0.098 \pm 0.013^{\mathrm{b}}$ & $0.049 \pm 0.008^{\mathrm{c}}$ \\
\hline C20:0 & $0.003 \pm 0.000^{\mathrm{a}}$ & $0.024 \pm 0.006^{\mathrm{b}}$ & $0.002 \pm 0.000^{\mathrm{a}}$ & $0.001 \pm 0.000^{\mathrm{a}}$ \\
\hline $\mathrm{C} 22: 0$ & $0.121 \pm 0.009^{\mathrm{a}}$ & $0.019 \pm 0.007^{\mathrm{b}}$ & $0.001 \pm 0.000^{\mathrm{c}}$ & $0.00 \pm 0.000$ \\
\hline ¿SFA & $1.820 \pm 0.109^{\mathrm{a}}$ & $1.365 \pm 0.057^{\mathrm{b}}$ & $0.723 \pm 0.019^{c}$ & $0.409 \pm 0.030^{\mathrm{d}}$ \\
\hline $\mathrm{C} 15: 1$ & $0.010 \pm 0.001^{\mathrm{a}}$ & $0.000 \pm 0.000$ & $0.002 \pm 0.000^{\mathrm{b}}$ & $0.002 \pm 0.000^{\mathrm{b}}$ \\
\hline C16: 1 & $0.217 \pm 0.025^{\mathrm{a}}$ & $0.136 \pm 0.022^{b}$ & $0.063 \pm 0.009^{\mathrm{c}}$ & $0.034 \pm 0.008^{\mathrm{d}}$ \\
\hline C18: 1 & $0.453 \pm 0.081^{\mathrm{a}}$ & $0.277 \pm 0.028^{\mathrm{b}}$ & $0.141 \pm 0.014^{\mathrm{c}}$ & $0.069 \pm 0.012^{\mathrm{d}}$ \\
\hline C20: 1 & $0.022 \pm 0.003^{\mathrm{a}}$ & $0.065 \pm 0.007^{\mathrm{b}}$ & $0.007 \pm 0.002^{\mathrm{c}}$ & $0.003 \pm 0.000^{\mathrm{d}}$ \\
\hline C22: 1 & $0.015 \pm 0.003^{\mathrm{a}}$ & $0.026 \pm 0.005^{b}$ & $0.001 \pm 0.000^{\mathrm{c}}$ & $0.000 \pm 0.000$ \\
\hline ¿MUFA & $0.702 \pm 0.054^{\mathrm{a}}$ & $0.525 \pm 0.040^{\mathrm{b}}$ & $0.214 \pm 0.005^{\mathrm{c}}$ & $0.108 \pm 0.003^{d}$ \\
\hline $\mathrm{C} 18: 2 \omega-6$ & $0.175 \pm 0.005^{\mathrm{a}}$ & $0.037 \pm 0.010^{\mathrm{b}}$ & $0.022 \pm 0.003^{\mathrm{c}}$ & $0.009 \pm 0.001^{\mathrm{d}}$ \\
\hline $\mathrm{C} 18: 3 \omega-6$ & $0.025 \pm 0.002^{\mathrm{a}}$ & $0.000 \pm 0.000$ & $0.005 \pm 0.002^{\mathrm{b}}$ & $0.003 \pm 0.001^{\mathrm{b}}$ \\
\hline$C 20: 2 \omega-6$ & $0.003 \pm 0.000^{\mathrm{a}}$ & $0.019 \pm 0.002^{b}$ & $0.002 \pm 0.000^{\mathrm{a}}$ & $0.001 \pm 0.00^{\mathrm{a}}$ \\
\hline $\mathrm{C} 20: 3 \omega-6$ & $0.016 \pm 0.002^{\mathrm{a}}$ & $0.011 \pm 0.001^{\mathrm{b}}$ & $0.001 \pm 0.000^{c}$ & $0.002 \pm 0.000^{c}$ \\
\hline$C 20: 4 \omega-6$ & $0.134 \pm 0.045^{\mathrm{a}}$ & $0.032 \pm 0.008^{b}$ & $0.017 \pm 0.003^{c}$ & $0.013 \pm 0.001^{\mathrm{c}}$ \\
\hline $\mathrm{C} 22: 5 \omega-6$ & $0.074 \pm 0.011^{\mathrm{a}}$ & $0.021 \pm 0.005^{\mathrm{b}}$ & $0.023 \pm 0.001^{\mathrm{b}}$ & $0.010 \pm 0.002^{\mathrm{c}}$ \\
\hline $\mathrm{C} 18: 3 \omega-3$ & $0.114 \pm 0.016^{\mathrm{a}}$ & $0.034 \pm 0.004^{\mathrm{b}}$ & $0.015 \pm 0.002^{\mathrm{c}}$ & $0.002 \pm 0.000^{\mathrm{d}}$ \\
\hline$C 18: 4 \omega-3$ & $0.023 \pm 0.004^{\mathrm{a}}$ & $0.120 \pm 0.016^{\mathrm{b}}$ & $0.043 \pm 0.005^{\mathrm{c}}$ & $0.022 \pm 0.001^{\mathrm{d}}$ \\
\hline$C 20: 3 \omega-3$ & $0.001 \pm 0.000^{\mathrm{a}}$ & $0.000 \pm 0.000$ & $0.001 \pm 0.000^{\mathrm{a}}$ & $0.000 \pm 0.000$ \\
\hline $\mathrm{C} 20: 4 \omega-3$ & $0.041 \pm 0.005^{\mathrm{a}}$ & $0.004 \pm 0.001^{\mathrm{b}}$ & $0.006 \pm 0.001^{\mathrm{b}}$ & $0.000 \pm 0.000$ \\
\hline $\mathrm{C} 20: 5 \omega-3$ & $0.345 \pm 0.071^{\mathrm{a}}$ & $0.086 \pm 0.003^{b}$ & $0.050 \pm 0.002^{\mathrm{c}}$ & $0.028 \pm 0.001^{\mathrm{d}}$ \\
\hline $\mathrm{C} 22: 5 \omega-3$ & $0.034 \pm 0.006^{\mathrm{a}}$ & $0.047 \pm 0.021^{\mathrm{a}}$ & $0.011 \pm 0.001^{\mathrm{b}}$ & $0.005 \pm 0.001^{\mathrm{c}}$ \\
\hline$C 22: 6 \omega-3$ & $1.303 \pm 0.093^{\mathrm{a}}$ & $0.351 \pm 0.013^{b}$ & $0.175 \pm 0.020^{c}$ & $0.115 \pm 0.014^{\mathrm{d}}$ \\
\hline $\mathrm{C} 16: 2$ & $0.624 \pm 0.064^{\mathrm{a}}$ & $0.403 \pm 0.092^{b}$ & $0.238 \pm 0.026^{c}$ & $0.157 \pm 0.019^{d}$ \\
\hline $\mathrm{C} 16: 3$ & $0.045 \pm 0.004^{\mathrm{a}}$ & $0.022 \pm 0.002^{b}$ & $0.008 \pm 0.002^{\mathrm{c}}$ & $0.005 \pm 0.001^{\mathrm{c}}$ \\
\hline $\mathrm{C} 16: 4$ & $0.032 \pm 0.003^{\mathrm{a}}$ & $0.027 \pm 0.008^{\mathrm{a}}$ & $0.015 \pm 0.002^{b}$ & $0.005 \pm 0.000^{c}$ \\
\hline $\mathrm{C} 21: 5$ & $0.022 \pm 0.008^{\mathrm{a}}$ & $0.000 \pm 0.000$ & $0.004 \pm 0.001^{\mathrm{b}}$ & $0.004 \pm 0.000^{\mathrm{b}}$ \\
\hline ¿PUFA & $2.670 \pm 0.212^{\mathrm{a}}$ & $1.214 \pm 0.002^{b}$ & $0.636 \pm 0.024^{\mathrm{c}}$ & $0.381 \pm 0.011^{\mathrm{d}}$ \\
\hline ¿UFA & $3.372 \pm 0.137^{\mathrm{a}}$ & $1.939 \pm 0.113^{b}$ & $0.850 \pm 0.098^{\mathrm{c}}$ & $0.489 \pm 0.062^{\mathrm{d}}$ \\
\hline PUFA ( $(\omega-3)$ & $1.861 \pm 0.176^{\mathrm{a}}$ & $0.642 \pm 0.249^{b}$ & $0.301 \pm 0.022^{\mathrm{c}}$ & $0.172 \pm 0.016^{\mathrm{d}}$ \\
\hline PUFA ( $\omega-6)$ & $0.427 \pm 0.082^{\mathrm{a}}$ & $0.120 \pm 0.026^{b}$ & $0.070 \pm 0.008^{c}$ & $0.038 \pm 0.005^{\mathrm{d}}$ \\
\hline$\sum F A$ & $5.192 \pm 0.312^{\mathrm{a}}$ & $2.579 \pm 0.640^{b}$ & $1.573 \pm 0.088^{c}$ & $0.898 \pm 0.036^{\mathrm{d}}$ \\
\hline
\end{tabular}

Values reported are mean \pm SD. Values in the same row followed by the same letters do not differ significantly $(\mathrm{p}>0.05)$ by Tukey's test, $\mathrm{n}=6$ SFA Saturated fatty acids, MUFA Monounsaturated fatty acids, PUFA Polyunsaturated fatty acids, $\sum F A$ Sum of fatty acids.

for host resources and the metabolic demands of the adult parasites resulted in the associated decreased values mainly in essential fatty acids. Herein, comparing with the control group (L0), the arachidonic acid (C20:4 $\omega-6$, ARA), EPA and DHA contents dropped by around $85 \%$ in L2 and by $90 \%$ in L3. Those fatty acids play key roles in growth, development processes and the modulation of the immune response in copepods (Fast et al., 2004; Leiknes et al., 2016). The hijack of these fatty acids from the 
host is an "easy way out" for parasites to acquire essential nutrients and the ability of selective diversion of these essential fatty acids from the host was signalled for other parasitic copepod (Hajji et al., 2015; Telahigue et al., 2017).

\subsection{Nutritional quality indices}

In the current study, the substantial changes observed in the fatty acid composition in relationship to the parasite load can negatively affect the nutritional quality of the fish for the human consumer. Health-related lipid indices such as atherogenic index (IA), thrombogenic index (IT), hypoc holesterolemic:hypercholesterolemic ratio $(\mathrm{H} / \mathrm{H})$, polyunsaturated fatty acid: saturated fatty acids (PUFA/SFA), $\omega-3 / \omega-6$ ratio, EPA and DHA levels are extensively used to assess the nutritional quality and the potential of fish oil to prevent diseases. The nutritional quality indices determined for different fish groups in this study are shown in Table 2.

The polyunsaturated and saturated fatty acid (PUFA/SFA) ratio is an index usually adopted to evaluate the nutritional quality of lipids in a diet. Diets with a PUFA/SFA ratio lower than 0.45 have been viewed as undesirable for the human diet due to their ability to increase cholesterol in the blood (Department of Health and Social Security, 1994). In our study, despite the fact that L. lusci infection has induced a significant reduction in this index $(0.88,0.87$ and 0.93 in L1, L2 and L3 groups respectively) when compared to the control (1.46), all recorded values were above the recommended rate.

The ratio of $\omega-3 / \omega-6$ is another good index widely used to assess the nutritional value of fish oil. As shown in Table 2, the obtained values for M. merluccius ranged from 4.30 and 5.35, and were insignificantly different among all the studied groups. In all cases, the reported values exceed the optimal nutritional ratio recommendations which vary from $1 / 1$ to $1 / 4$. Our findings are in agreement with Hossain
(2011), who reported that in general, fish lipids and fish products have a much higher $\omega-3 / \omega-6$ ratio than what is recommended. According to the same author, the elevated $\omega-3 / \omega-6$ ratio is highly beneficial for the daily human diet. However, other authors stress that this index is of limited value without consideration of which fatty acids are present (Arts et al., 2001). Furthermore, according to Wijendran and Hayes (2004), the intake of PUFA (mainly EPA and DHA) expressed in terms of mass ( $\%$ en or $\mathrm{g} / \mathrm{d})$ is a more optimal approach to a dietary $\omega-3$ and $\omega-6$ fatty acid balance than a simple ratio.

The beneficial effects of EPA and DHA in animal models and humans are very well documented. They are known to exert anti-inflammatory action (Calder 2010) and are considered as potent hypotriacyl glycerolemic and antiarrhythmic agents (Billman et al., 1999). According to the US Department of Agriculture and U.S. Department of Health and Human Services (2010), an average of $250 \mathrm{mg} /$ day of EPA+DHA is required for individuals at both higher and average cardiovascular disease risks. However, the American Heart Association recommends about $1.0 \mathrm{~g} /$ day of EPA and DHA to reduce the risk of death from coronary heart disease (KrisEtherton et al., 2003). On the other hand, a daily intake of $0.2 \mathrm{~g}$ of EPA and DHA is proposed by the British Nutrition Foundation (2009) for people with balanced and healthy diets. In our study, the results reported in Table 2 show that among the analyzed groups, the unparasitezed fish had the highest combined EPA and DHA level (160.48 mg/100 g wet wt). The recorded level is below those previously reported for other Gadidae species such as $M$. productus (240 mg/100 g) (Huynh and Kitts, 2009) and $M$. hubbsi (440 mg/100 g) (Mendez and Gonzalez, 1997). In fact, the amount of EPA+DHA in fish is highly variable and strongly dependent on several parameters such as species, dietary intake, lipid content and the size of the fish (Huynh and Kitts, 2009; Tocher et al., 2010; Strandberg et al., 2017). The current

TABLE 2. Nutritional quality indices of the fillet of the unparasitized and parasitized Merluccius merluccius with different Lernaeocera lusci loads (L1: one single parasite, L2: two parasites and L3: three parasites per host).

\begin{tabular}{|c|c|c|c|c|}
\hline Indices & $\begin{array}{c}\text { Control } \\
\text { L0 }(\text { Load = 0) }\end{array}$ & $\begin{array}{l}\text { Parasitized } \\
\text { L1 (load=1) }\end{array}$ & $\begin{array}{c}\text { Parasitized } \\
\text { L2 }(\text { Load = 2) }\end{array}$ & $\begin{array}{c}\text { Parasitized } \\
\text { L3 }(\text { Load = 3) }\end{array}$ \\
\hline$\omega-3 / \omega-6$ & $4.36 \pm 0.36^{\mathrm{a}}$ & $5.35 \pm 0.49^{\mathrm{a}}$ & $4.30 \pm 0.15^{\mathrm{a}}$ & $4.52 \pm 0.45^{\mathrm{a}}$ \\
\hline $\mathrm{EPA}+\mathrm{DHA}(\mathrm{mg} / 100 \mathrm{~g}$ wet $\mathrm{wt})$ & $160.48 \pm 5.91^{\mathrm{a}}$ & $40.37 \pm 2.9^{\mathrm{b}}$ & $20.25 \pm 2.52^{\mathrm{c}}$ & $10.43 \pm 0.85^{\mathrm{d}}$ \\
\hline PUFA/SFA & $1.46 \pm 0.12^{\mathrm{a}}$ & $0.88 \pm 0.09^{\mathrm{b}}$ & $0.87 \pm 0.19^{\mathrm{b}}$ & $0.93 \pm 0.31^{\mathrm{b}}$ \\
\hline AI & $0.66 \pm 0.06^{\mathrm{a}}$ & $0.98 \pm 0.12^{\mathrm{b}}$ & $1.35 \pm 0.11^{\mathrm{c}}$ & $1.16 \pm 0.21^{\mathrm{bc}}$ \\
\hline TI & $0.26 \pm 0.02^{\mathrm{a}}$ & $0.43 \pm 0.07^{\mathrm{b}}$ & $0.45 \pm 0.05^{\mathrm{b}}$ & $0.33 \pm 0.08^{\mathrm{b}}$ \\
\hline $\mathrm{H} / \mathrm{H}$ & $1.81 \pm 0.15^{\mathrm{a}}$ & $0.96 \pm 0.05^{\mathrm{b}}$ & $0.75 \pm 0.09^{\mathrm{b}}$ & $0.82 \pm 0.10^{\mathrm{b}}$ \\
\hline
\end{tabular}

Values reported are mean \pm SD. Values in the same column followed by the same letters do not differ significantly $(p>0.05)$ by Tukey's test, $n=6$.

AI atherogenic index, TI thrombogenic index, H/H hypocholesterolemic/hypercholesterolemic fatty acid ratio, EPA eicosapentaenoic acid (C20:5 $\omega-3)$, DHA docosahexaenoic acid (C22:6 $\omega 3)$. 
study revealed that the $L$. lusci infection considerably reduced the EPA+DHA contents of M. merluccius fillet ( $<<0.05$ ), which fell to 40.37, 20.25 and 10.43 $\mathrm{mg} / 100 \mathrm{~g}$ wet wt in L1, L2 and L3 groups, respectively (Table 2). These amounts account for 16, 8 and $4 \%$, respectively, of the minimum recommended daily requirements of $250 \mathrm{mg} /$ day.

To further ascertain the global dietetic quality of lipids and their potential effect on the development of coronary disease, other indices based on the functional effects of different fatty acids are often used. Ulbricht and Southgate (1991) proposed two indices: IA (atherogenic index) and IT (thrombogenic index), which might better characterize the atherogenic and the thrombogenic potential of fatty acids (Hosseini et al., 2014). It is assumed that lipids with higher values of IA and TI $(>1.0)$ are detrimental to human health (Stancheva et al., 2014).

In addition to these indices, the hypocholesterolemic and hypercholesterolemic fatty acid ratio $(\mathrm{H} / \mathrm{H})$, which considers the specific effects of fatty acids on cholesterol metabolism, is a confirmed indicator of the cholesterolemic value of the lipid source (Fernandes et al., 2014). From a nutritional standpoint, high $\mathrm{H} / \mathrm{H}$ values are considered more beneficial for human health. Among the current studied groups, the unparasitezed one presented the greatest $\mathrm{H} / \mathrm{H}$ (1.81) followed by the L1 group (0.96) while L2 and L3 groups showed the lowest values (Table 2).

Thus, unlike the $\mathrm{H} / \mathrm{H}$ index, the lower the value of both indices, the better the nutritional quality of the fatty acids and vice versa. In the current study, the IA and IT indices of unparasitezed fish were 0.66 and 0.26 , respectively (Table 2 ). The $L$. lusci infection had significantly increased the IA as well as the IT in all the parasitized groups $(\mathrm{p}<0.05)$ when compared to the control group. However, a more pronounced negative effect was observed for IA since it exceeded the recommended value for a healthy diet. In the parasitized group, the higher values of IA and IT are related to the lower contents of PUFA and MUFA when compared to the control. In addition, the low levels of the $\mathrm{H} / \mathrm{H}$ ratio of the parasitized hake are related to the low content of the hypocholesterolemic fatty acids

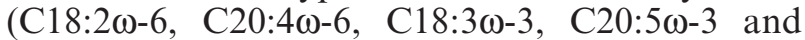
C22:6 $\omega-3)$. Hence, the consumption of parasitized hake could increase the intake of cholesterol, atherogenic and thrombogenic fats that have negative health implications particularly for patients on a special healthy diet. It is obvious that these substances are strongly connected with the increase in the incidence of pathogenic phenomena, such as atheroma and/or thrombus formation (RafieianKopaei et al., 2014). Therefore, the present study emphasizes the need to take into consideration the prevalence of parasitic species such as L. Lusci, which can reach more than $30 \%$, for recommended fish species in health and disease prevention.

\section{CONCLUSIONS}

This study is the first to assess the impact of the parasitic copepod $L$. lusci on the fat and fatty acid composition of its definitive host $M$. merluccius concerning the infection intensity. In contrast to the little available data which assumed that $L$. lusci exerted minor damage to its host, our results revealed that this pathogen is able to cause a severe reduction in its host's lipid fraction and may deteriorate its nutritional quality. The modest amount of DHA and EPA mainly recorded at heavy infection rates makes the parasitized fish an inadequate sources of these PUFA and unsuitable for consumers who follow a specific diet.

\section{ACKNOWLEDGMENTS}

The authors are grateful to the editor and the anonymous reviewers for their acceptance to review this work and their valuable comments and suggestions to improve the quality of the manuscript.

\section{REFERENCES}

Arts MT, Ackman RG, Holub BJ. 2001. "Essential fatty acids" in aquatic ecosystems: A crucial link between diet and human health and evolution. Can. J. Fish Aquat. Sci. 58,122-137. https://doi.org/10.1139/f00-224

Billman GE, Kang JX, Leaf A. 1999. Prevention of sudden cardiac death by dietary pure omega-3 polyunsaturated fatty acids in dogs. Circulation 99, 2452-2457. https://doi.org/ 10.1161/01.cir.99.18.2452

British Nutrition Foundation. 1992. Unsaturated fatty acids: nutritional and physiological significance. Report of British Nutrition Foundation: Chapman \& Hall. London.

Calder PC. 2010. Omega-3 Fatty Acids and Inflammatory Processes. Nutrients 2, 355-374. https://doi.org/10.3390/nu 2030355

Cecchi G, Basini S, Castano C. 1985. Méthanolyse rapide des huiles en solvant. Rev. Fr. Corps Gras 4, 63-164.

Connor WE. 2000. Importance of $n-3$ fatty acids in health and disease. Am. J. Clin. Nutr. 71, 171S-175S. https://doi.org/ 10.1093/ajen/71.1.171S

Corrales GP, Rivero NL. 2013. Role of hake as a source of omega-3 fatty acids in cardiovascular disease prevention. Clin. Nutr. 32, 660. https://doi.org/10.1016/j.clnu.2013.04.016

Department of Health and Social Security. 1994. Nutritional aspects of cardiovascular disease. Report of the Cardiovascular Review Group Committee on Medical Aspects of Food Policy. Rep. Health Soc. Subj. (Lond) 46, $1-186$.

Eiras JC. 1986. Some aspects of the infection of bib, Trisopterus luscus (L.), by the parasitic copepod Lernaeocera lusci (Bassett-Smith, 1896) in Portuguese waters. J. Fish Biol. 28, 141-145. https://doi.org/10.1111/j.1095-8649.1986.tb05151.x

Evans NA, Whitfield PJ, Bamber N, Espin PM. 1983. Lernaeocera lusci (Copepoda: Pennellidae) on bib (Trisopterus luscus) from Southampton Water. Parasitology 86, 161-173. https://doi.org/10.1017/S0031182000057267

Fast MD, Ross NW, Craft CA, Locke SJ, Mackinnon SL, Johnson SC. 2004. Lepeophtheirus salmonis: characterization of prostaglandin E2 in secretory products of the salmon louse by RP-HPLC and mass spectrometry. Exp. Parasitol. 107, 5-13. https://doi.org/10.1016/j.exppara.2004.04.001 
Fernandes CE, Vasconcelos MA, Ribeiro MdeA, Sarubbo LA, Andrade SA, Filho AB. 2014. Nutritional and lipid profiles in marine fish species from Brazil. Food Chem. 160, 67-71. https://doi.org/10.1016/j.foodchem.2014.03.055

Folch J, Lees M, Sloane-Stanley GA. 1957. A simple method for the isolation and purification of total lipids from animal tissues. J. Biol. Chem. 226, 497-509.

Hajji T, Telahigue K, Bennour S, Gharbi M, El Cafsi M. 2015. Impact of Peroderma cylindricum (Copepoda: Pennellidae) infection on fatty acid composition and lipid quality of sardine (Sardina pilchardus). J. Parasitol. 101, 682-686. https://doi.org/10.1645/15-777

Hossain MA. 2011. Fish as source of $n$-3 Polyunsaturated Fatty Acids (PUFAs), which one is better-farmed or wild? $A d v$. $J$. Food Sci. Technol. 3, 455-466.

Hosseini H, Mahmoudzadeh M, Rezaei M, Mahmoudzadeh LK, Babakhani A. 2014. Effect of different cooking methods on minerals, vitamins and nutritional quality indices of kutum roach (Rutilus frisii kutum). Food Chem. 148, 86-91. https://doi.org/10.1016/j.foodchem. 2013.10.012

Huynh MD, Kitts DD. 2009. Evaluating nutritional quality of pacific fish species from fatty acid signatures. Food Chem. 114, 912-918. https://doi.org/10.1016/j.foodchem. 2008.10.038

Khan RA. 1988. Experimental transmission, development, and effects of a parasitic copepod, Lernaeocera branchialis, on Atlantic cod, Gadus morhua. J. Parasitol. 74, 586-599. https://doi.org/10.2307/3282174

Kris-Etherton PM, Harris WS, Appel LJ. 2003. Omega-3 fatty acids and cardiovascular disease: New recommendations from the American Heart Association. Arterioscler. Thromb. Vasc. Biol. 23,151-152. https://doi.org/10.1161/01. ATV.0000057393.97337.AE

Leiknes O, Etter S A, Tokle NE, Bergvik M, Vadstein O, Olsen Y. 2016. The effect of essential fatty acids for the somatic growth in nauplii of Calanus finmarchicus. Front. Mar. Sci. 3, 33. https://doi.org/10.3389/fmars.2016.00033

Mendez E, Gonzalez RM. 1997. Seasonal changes in the chemical and lipid composition of fillets of the Southwest Atlantic hake (Merluccius hubbsi). Food Chem. 59, 213-217. https://doi.org/10.1016/S0308-8146(96)00225-7

Rafieian-Kopaei M., Setorki M, Doudi M, Baradaran A, Nasri H. 2014. Atherosclerosis: Process, Indicators, Risk Factors and New Hopes. Int. J. Prev. Med. 5, 927-946.

R Core Team. 2017. R: A Language and Environment for Statistical Computing. R Foundation for Statistical Computing. Vienna, Austria.

Ruxton CH, Reed SC, Simpson MJ, Millington KJ. 2004. The health benefits of omega- 3 polyunsaturated fatty acids: a review of the evidence. J. Hum. Nutr. Diet. 17, 449-459. https://doi.org/10.1111/j.1365-277X.2004.00552.x
Santos-Silva J, Bessa RJB, Santos-Silva F. 2002. Effects of genotype, feeding system and slaughter weight on the quality of light lambs: II. Fatty acid composition of meat. Livest. Prod. Sci. 77, 187-194. https://doi.org/10.1016/ S0301-6226(02)00059-3

Satio H, Yamashiro R, Alasalvar C, Konno T. 1999. Influence of diet on fatty acids of three subtropical fish, subfamily Caesioninae (Caesio digrumna and C. tile) and family siganidae (Siganus canaliculatus). Lipids 34, 1073-1082.

Smith JL, Wootten R, Sommerville C. 2007. The pathology of the early stages of the crustacean parasite, Lernaeocera branchialis (L.), on Atlantic cod, Gadus morhua (L). J. Fish Dis. 30,1-11. https://doi.org/10.1111/j.1365-2761.2007.00787.x

Stancheva M, Merdzhanova A, Dobreva DA, Makedonski L. 2014. Common carp (Cyprinus carpio) and European catfish (Silurus glanis) from Danube River as sources of fat soluble vitamins and fatty acids. Czech. J. Food Sci. 32, 16-24.

Strandberg U, Bhavsar SP, Arts MT. 2017. Estimation of omega-3 fatty acid (EPA + DHA) intake from Lake Ontario fish based on provincial consumption advisories. $J$. Great Lakes Res. 43, 1132-1140. https://doi.org/10.1016/j. jglr.2017.08.009

Swanson D, Block R, Mousa SA. 2012. Omega-3 fatty acids EPA and DHA: health benefits throughout life. Adv. Nutr. 3, 1-7. https://doi.org/10.3945/an.111.000893

Telahigue K, Haiji T, Gharbi M, Cherif A, El Cafsi M. 2017. The parasitic copepod Peroderma cylindricum Heller, 1865 (Copepoda: Pennellidae) and its host Sardina pilchardus (Walbaum, 1792): trophic relationships as revealed by fatty acid profiles. J. Crustacean Biol. 37, 453-457. https://doi. org/10.1093/jcbiol/rux054

Tocher JA, Dick JR, Bron JE, Shinn AP, Tocher DR. 2010. Lipid and fatty acid composition of parasitic caligid copepods belonging to the genus Lepeophtheirus. Comp. Biochem. Physiol. B. 156, 107-114. https://doi.org/10.1016/j.cbpb. 2010.02 .010

US Department of Agriculture and U.S. Department of Health and Human Services. 2010. Dietary Guidelines for Americans. $7^{\text {th }}$ edition, Washington, DC: US Government printing office.

Ulbricht TL, Southgate DA. 1991. Coronary heart disease: seven dietary factors. Lancet 338, 985-92.

Van Damme PA, Ollevier F, Hamerlynck O. 1994. Pathogenicity of Lernaeocera lusci and L. branchialis in bib and whiting in the North Sea. Dis. Aquat. Organ. 19, 61-65. https://doi. org/10.3354/dao019061

Wijendran V, Hayes KC. 2004. Dietary $n-6$ and $n-3$ fatty acid balance and cardiovascular health. Annu. Rev. Nutr. 24, 597-615. https://doi.org/10.1146/annurev.nutr.24.012003. 132106

Woo PTK, Buchmann K. 2012. Fish Parasites: Pathobiology and Protection. CAB International, Wallingford. 